\title{
Screening for Down's syndrome
}

\section{New methods allow detection of three fifths of affected pregnancies}

Policies on screening for Down's syndrome vary from region to region in Britain, but most offer amniocentesis at about 16 weeks' gestation to women aged 35 or over. If all such women have the test then $7 \cdot 5 \%$ of pregnancies will require amniocentesis and $35 \%$ of cases in which the fetus has Down's syndrome will be detected. Many attempts have been made to improve the rate of detection without having to expose many more women to amniocentesis, but a method described in this issue by Wald and others ( $p$ 883) is the first that will detect $60 \%$ of affected pregnancies while requiring only $5 \%$ of women to undergo amniocentesis.

The chance to improve yields while exposing fewer women to amniocentesis began with the observation that a low serum concentration of $\alpha$ fetoprotein in the mother was associated with Down's syndrome in the fetus. ${ }^{12}$ It was then shown that the serum concentration of $\alpha$ fetoprotein in the mother could be used alone to identify pregnancies that were at risk. ${ }^{3}$ Subsequently Cuckle et al showed that better definition of a high risk group could be obtained by combining risks derived from the serum concentration of $\alpha$ fetoprotein in the mother and maternal age. ${ }^{+}$With this approach $35 \%$ of pregnancies in which the fetus has Down's syndrome should be identifiable at a rate of amniocentesis of only $5 \%$.

Still better results may be obtained by deriving risks from the serum concentration of unconjugated oestriol, the serum concentration of $\alpha$ fetoprotein in the mother, and maternal age: this will allow detection of $45 \%$ of affected pregnancies with a $5 \%$ amniocentesis rate. ${ }^{56}$ The concentration of human chorionic gonadotrophin may also be used as a screening test for high risk pregnancies, ${ }^{7}$ and Wald and others have used a composite risk calculated from maternal age, the serum concentration of $\alpha$ fetoprotein in the mother, and the serum concentrations of unconjugated oestriol and human chorionic gonadotrophin to achieve their outstanding results.

It would be unrealistic to suppose that Britain will switch quickly from screening for Down's syndrome based on maternal age to screening based on a composite risk derived from age and several serum factors. Those health districts or regions already using screening based on the serum concentration of $\alpha$ fetoprotein in the mother for detecting neural tube defects should have a system for recall and venepuncture at 16 weeks of pregnancy and would need only to provide resources for the other serum tests. The savings resulting from a lower rate of amniocentesis and an improved rate of detection of Down's syndrome may well provide these resources.
The problems inherent in introducing a new screening strategy should not, however, be underestimated. Pregnant women and those who provide their antenatal care may not be convinced that those women with low composite risks who would have been screened because of age alone should no longer be offered amniocentesis. ${ }^{8}$ Even with supportive counselling there will be the "bombshell" effect for women under 35 with high composite risks who had not previously thought themselves to be at increased risk. A screening programme with the serum samples taken at 16 weeks' gestation will lead to later amniocentesis and late terminations of pregnancy and is in direct conflict with the aim of offering prenatal diagnosis by chorionic villus biopsy in the first trimester. Perhaps the new screening strategy should be reserved for women under 38 and efforts made to provide chorionic villus biopsy for all women aged 38 and over.

The King's Fund consensus statement on screening for fetal and genetic abnormality recommended a coordinated strategy for screening programmes and emphasised the need for both adequate technical resources and genetic and supportive counselling. ${ }^{9}$ More financial resources will be needed for this comprehensive approach. The difficulty is as ever to balance the wishes of an individual woman and her personal risk against the benefits of population screening programmes with high rates of detection such as that described by Wald and others.

DIAN DONNAI

Consultant Clinical Geneticist

TONY ANDREWS

Director, Regional Cytogenetics Service

Regional Genetics Service,

St Mary's Hospital,

Manchester M13 0JH

1 Merkatz IR, Nitowsky HM, Macri JN, Johnson WE. An association between low maternal serum alpha-fetoprotein and fetal chromosome abnormalities. Am F Obstet Gynecol 1984;14:886-92.

Cuckle HS, Wald NJ, Lindenbaum RH. Maternal serum alpha-fetoprotein measurements: a screening test for Down's syndrome. Lancet 1984;: $926-9$.

Murday V, Slack J. Screening for Down's syndrome in the North East Thames Region. Br Med $\mathcal{F}$ 1985;291:1315-8.

4 Cuckle HS, Wald NJ, Lindenbaum RH. Screening for Down's syndrome using serum $\alpha$ fetoprotein. BrMed I 1985;291:349.

5 Canick JA, Knight GJ, Palomaki GE, Haddow JE, Cuckle HS, Wald NJ. Low second trimester Canick JA, Knight GJ, Palomaki GE, Haddow JE, Cuckle HS, Wald NJ. Low second trimester
maternal serum unconjugated oestriol in pregnancies with Down's syndrome. Br f Obstet
Gynaecol 1988:95:330-3.

6 Wald NJ, Cuckle HS, Densem JW, et al. Maternal serum unconjugated oestriol as an antenatal screening test for Down's syndrome. Br f Obstet Gynaecol 1988;95:334-41.

7 Bogart MH, Pandian MR, Jones OW. Abnormal maternal serum chorionic gonadotrophin levels in pregnancies with fetal chromosome abnormalities. Prenat Diagn 1987; 7:623-30.

8 Harris R, Andrews T. Prenatal screening for Down's syndrome. Arch Dis Child 1988;63:705-6.

9 King's Fund Forum. Consensus statement. Screening for fetal and genetic abnormality. Br Med $\mathcal{F}$ 1987;295:1551-3. 